\title{
AN ANALYSIS OF RHETORICAL MOVE AND TRANSLATION TECHNIQUES IN UNDERGRADUATE THESIS ABSTRACTS WRITTEN IN TWO LANGUAGES
}

\author{
1Zalinda Salsabilla Firdausyiah (D), ${ }^{2}$ Budi Hermawan (D), \\ ${ }^{3}$ Dian Dia-an Muniroh \\ 1,2,3 Universitas Pendidikan Indonesia \\ Corresponding email: zalindasf@upi.edu
}

\begin{abstract}
An abstract is a brief overview of a research paper. Indonesian undergraduate students are often required to submit their thesis abstracts in Indonesian and English. Various studies related to rhetorical move and translation techniques of abstracts have been done previously, but not many analyzed undergraduate students' thesis abstracts across languages. Therefore, this study aims to analyze the move-step of the abstracts, and to see translation techniques in different abstract moves. This study used 60 undergraduate thesis abstracts from English Language and Literature and Indonesian Language Literature study programs as the data. As the framework for the data analysis, this study employed Hyland's (2000) five-move model and Molina \& Albir's (2002) translation techniques. The findings show that despite writing in different languages, both Indonesian and English abstracts were realized with similar rhetorical moves and steps. Move 3 and 4 were found in all of the abstracts, while Move 5 was only realized in small numbers across languages. In relation to translation techniques, it is found that Literal translation is used more frequently than other translation techniques. This study recommends a more extensive study that involves more data from different fields to expand the existing knowledge relating to rhetorical move and translation techniques in the academic field, especially in undergraduate students' abstracts.
\end{abstract}

Keywords: abstracts, rhetorical move, steps, translation techniques, undergraduate

\section{INTRODUCTION}

An abstract serves as one of the most important elements of a research paper. It represents the content of a paper in a more condensed way and helps readers gain a preview of information in a quick and comprehensive way (Cross \& Oppenheim, 2006; Koltay, 2010; Kurniawan et al., 2019). In addition, 
an abstract acts as an outline to help the readers understand its full content (Koltay, 2010). In short, an abstract is a concise text that helps the reader to get the gist of the content and know what to expect by serving the main points of a paper. Due to its functions, an abstract is most likely to be read first by the reader to determine whether a paper is worth reading or not. However, certain characteristics should be present in an abstract in order for it to be functional: brevity, exhaustivity, accuracy, density, clarity, and content (Cross \& Oppenheim, 2006).

Abstracts are often arranged in a rhetorical pattern relevant to its discipline and due to its diversity, writing an abstract targeted for publication in a journal becomes a challenge (Kurniawan et al., 2019). In a more general sense, Bhatia (1993) suggested that an abstract contains information on four aspects of a research paper: what was done in the research, how the research was done, what was found in the research, and what was concluded from the research. From those questions, Bhatia (1993) developed four moves: Introducing purpose, Describing Methodology, Summarizing Results, and Presenting Conclusions. Based on his research using a corpus consisting of 800 abstracts, Hyland (2000) further developed Bhatia's four categories of moves into a five-move model. The five-model consists of Introduction, Purpose, Method, Product, and Conclusion. The understanding of move through move analysis helps to raise comprehension of standard moves realization in an abstract (Kurniawan et al., 2019).

In order to achieve international publication, a research paper must be written in English. If it is not written in English, the source text (ST) must be translated into English. For a similar reason, undergraduate thesis abstracts written in Indonesian must be written in English. Writing abstracts in English can be a challenge for students who are not used to writing in English. This can be understood as English is not the first language of most Indonesian students. Students may resort to translating their abstracts word-to-word, or even use an online translation engine such as Google Translate. Past studies had concluded that online translation engines were unable to produce perfectly translated texts and a considerable amount of grammatical revisions were needed (Groves \& Mundt, 2015; Sukmawati et al., 2021).

Bassnett (2014) stated that translating is a common activity as an impact of a rapid increase of access to media all over the world. Translation is defined as the process of transferring a text from its source language to a target language. In an academic context, translation holds an important role in the process of knowledge transfer. If an academic text is not properly translated, the process of knowledge transfer may not be done properly. Poor translation quality may not only change the structure of the translated abstract, but also omit some parts and decrease the overall functionality of the abstract. Other than that, poor translation quality could possibly hinder the paper from being 
published. Consequently, the paper will not be discovered and read by a wide range of audience as well. Therefore, it is highly important to write and translate an abstract well.

In relation to translation, translation techniques have been proposed by researchers in this field. Translation techniques refer to the instrument of textual analysis that allows one to understand how translation works (Molina \& Albir, 2002). Many experts have proposed various translation techniques Nida's (1964) techniques of adjustment and Newmark's (1988) procedures, to name a few. However, the techniques proposed by those experts seem to differentiate method, strategy, and technique whereas according to Hurtado (1996, as cited in Molina \& Albir, 2002), those three terms refer to similar activities. Thus, Molina and Albir proposed their own approach to translation techniques that were derived from existing methods, strategies, and techniques. The classification of techniques include adaptation, amplification, borrowing, calque, compensation, description, discursive creation, established equivalent, generalization, linguistic amplification, linguistic compression, literal translation, modulation, particularization, reduction, substitution, transposition, and variation. With its variety, this technique is expected to be able to distinguish between translation method, strategy, and technique.

Many researchers have conducted studies in the past about moves in research abstracts using Hyland's (2000) five-move theory. Chalak \& Norouzi's (2013) study that analyzed the rhetorical moves in American and Iranian abstracts revealed that Move 2 (Purpose), Move 3 (Method), and Move 4 (Result) were considered obligatory while the rest were optional moves. In a similar context, Darabad (2016) conducted an analysis of rhetorical moves in research article abstracts across disciplines. The study found that Introduction is the move that was found the least, while Purpose and Product moves were found the most in all of the examined abstracts. Rashidi \& Meihami's (2018) study that investigated abstracts of articles published in Scientometrics showed that Method and Product were the moves that appeared the most, while the move that appeared least was Conclusion. Amnuai (2019) conducted a similar research with RA from Thai and International accounting journals. The study finds that Purpose and Product were used the most frequently. From those studies, it is shown that Move 4 (Product or Result) is a Move that occurred the most frequently in the abstracts.

In the field of translation, there are several studies that used Molina \& Albir's (2002) translation techniques to identify translation techniques in various texts. For instance, Anwar et al. (2020) employed the framework to analyze translation techniques in Aladdin's movie script. The findings of their study showed that linguistic compression was used the most prominently at 
$56.52 \%$, while other techniques occurred less frequently (10\% and below). Kuswahono (2020) used the technique to identify translation techniques of a novel. His study revealed that six techniques were employed. Pure borrowing is the most frequently used technique with 188 occurrences, followed by transposition with 23 occurrences. Not only literature texts, the translation techniques have been used for example to analyze religious texts as well, such as a translation technique analysis of Quranic metaphor or kinayah by $\mathrm{Al} \mathrm{Farisi}$ (2020). The result showed that the application of literal translation presented the primary meaning of the kinayah verses accurately while amplification presents the secondary meaning transparently with target language as the orientation. Another type of religious text that went through an analysis using Molina \& Albir's (2002) translation techniques is religious tourism brochure (Sodiq et al., 2020). The result revealed that pure borrowing is the technique that was identified the most with $41 \%$ frequency, followed by pure borrowing-established equivalent with $17 \%$ frequency. While the results of these previous studies differ, it shows a similarity where there is a noticeable gap between the translation technique that occurred the most and the rest.

As can be seen from the existing previous studies, analysis of the rhetorical pattern of undergraduate abstracts is still quite scarce. Analysis of translation techniques of undergraduate level abstract is not something that has been explored a lot as well. Therefore, this study aimed to identify and analyze the rhetorical moves and translation techniques in undergraduate thesis abstracts across Indonesian and English languages using Hyland's (2000) five-move model and Molina and Albir's (2002) translation techniques. This article will attempt to answer the following questions:

1. How is the rhetorical organization of the abstracts written in English and translated into Indonesian and vice versa illustrated in thesis abstracts and its translated version?

2. What are translation techniques employed to translate the thesis abstracts written in English and translated into Indonesian and vice versa?

\section{METHODS}

This is a qualitative study that analyzes undergraduate students' abstracts. This study intended to identify rhetorical moves and translation techniques that were used by undergraduate students in writing their thesis research abstract across languages.

\section{Subject}

To fulfill the aim of the study, the abstracts that were taken as data must be written in two languages. The abstracts were extracted from the theses of undergraduate English Language and Literature and Indonesian Language 
and Literature students. The study programs were chosen because English Language and Literature students were required to write their thesis abstract in English first, while Indonesian Language and Literature students wrote their thesis abstract in Indonesian first.

The data consists of a corpus of 60 abstracts -30 abstracts in its source language and 30 abstracts in its target language. 30 abstracts were taken from English Language and Literature undergraduate theses with 15 written in English and 15 translated to Indonesian, and 30 abstracts were taken from Indonesian Language and Literature thesis with 15 written in Indonesian and 15 written in English.

\section{Data Collection}

First, the researchers determined the subject field of the data that would be analyzed. Second, the researchers accessed Universitas Pendidikan Indonesia's online repository website. Third, the theses abstracts were checked starting from the most recently published. If it was written in English and Indonesian, the abstracts were chosen. Fourth, the abstracts were copied and compiled according to its study program and language into a file with docx format. The title, author name, and year of publication were written on top of the abstract.

\section{Data Analysis Procedures}

Two analyses were done to reach the aim of this study. There are move analysis and translation technique analysis. Move analysis employed Hyland (2000)'s five-move as the framework (see Table 1). The data analysis procedure consisted of several steps.

Table 1. Hyland's (2000) Five-move Analysis Guide

\begin{tabular}{|c|c|c|}
\hline Move & Step & Description \\
\hline \multirow[t]{4}{*}{ Introduction (I) } & S1 & Arguing for topic significance \\
\hline & S2 & Making topic generalization \\
\hline & S3 & Defining key term(s) \\
\hline & S4 & Identifying gap \\
\hline Purpose (P) & & Stating the research purpose \\
\hline \multirow[t]{3}{*}{ Method (M) } & S1 & Describing the participants/data sources \\
\hline & S2 & Describing the instrument(s) \\
\hline & S3 & Describing the procedure and context \\
\hline Purpose (Pr) & & Describing the main results \\
\hline \multirow[t]{4}{*}{ Conclusion (C) } & S1 & Deducing conclusion \\
\hline & S2 & Evaluating the significance of the research \\
\hline & S3 & Stating limitation \\
\hline & S4 & Presenting recommendation or implication \\
\hline
\end{tabular}


Note. Adopted from “Disciplinary Discourse: Social Interactions in Academic Writing" by K Hyland. 2002, University of Michigan Press. Copyright 2019 by University of Michigan.

The sentences were broken down into sentences as the unit of analysis, both for the move analysis and translation techniques analysis. To analyze the rhetorical moves, the sentences were then put into tables and then labeled according to its move and step category. For the rhetorical move analysis, both abstracts written in the source language (SL) and the target language (TL) are analyzed to see whether there are moves and steps that are omitted or not. The occurrence of each move and step were then counted using tally marks and processed in excel to see the percentage of the occurrence. Table 3 shows the result of the calculation.

Molina \& Albir's (2002) translation techniques (see Table 2) were used as the theoretical framework to analyze the translation techniques. The analysis steps were as follows. First, the sentences of the abstracts written in source language (SL) and target language (TL) were put next to each other in a table, which is made for the analysis process. The authors paid attention to the sentence structure and overall translation to determine which translation technique is used. The translation techniques identified were written in a column. After all of the sentences were analyzed, the analysis result was crosschecked by researcher 2 and researcher 3 for accuracy.

Similarly, the occurrence of translation techniques were also counted using tally marks first before processed in excel to see the percentage. The result is presented in Table 4 .

Table 2. Molina and Albir's (2002) Classification of Translation Techniques

\begin{tabular}{ll}
\hline \multicolumn{1}{c}{ Translation technique } & \multicolumn{1}{c}{ Description } \\
\hline Adaptation & $\begin{array}{l}\text { Replacement of a source text's cultural } \\
\text { element to a suitable cultural element in } \\
\text { the target text } \\
\text { Introduction of details that are not } \\
\text { formulated in the source text } \\
\text { Use of a word or expression from another } \\
\text { language }\end{array}$ \\
Calque & $\begin{array}{l}\text { Literal translation of a foreign word or } \\
\text { phrase }\end{array}$ \\
Compensation & $\begin{array}{l}\text { Introduction of a source text element of } \\
\text { information or stylistic effect in another } \\
\text { place in the target text } \\
\text { Replacement of a term or expression with } \\
\text { a description of its term or function }\end{array}$ \\
\hline
\end{tabular}




\begin{tabular}{|c|c|}
\hline Translation technique & Description \\
\hline Discursive creation & $\begin{array}{l}\text { Establishment of a temporary } \\
\text { equivalence that is unpredictable and out } \\
\text { of context }\end{array}$ \\
\hline Established equivalent & $\begin{array}{l}\text { Use of a term or expression that is } \\
\text { recognized (in dictionaries or language } \\
\text { in use) as the equivalent }\end{array}$ \\
\hline Generalization & Use of a more general or neutral term \\
\hline Linguistic amplification & Addition of linguistic elements \\
\hline Linguistic compression & $\begin{array}{l}\text { Synthetization of linguistic elements in } \\
\text { the target text }\end{array}$ \\
\hline Literal translation & $\begin{array}{l}\text { Translation of a word or an expression } \\
\text { for word }\end{array}$ \\
\hline Modulation & $\begin{array}{l}\text { Change of the point of view or focus in } \\
\text { relation to the source text }\end{array}$ \\
\hline Particularization & Use of a more precise term \\
\hline Reduction & $\begin{array}{l}\text { Suppression of information from the } \\
\text { source text in the target text }\end{array}$ \\
\hline Substitution & $\begin{array}{l}\text { Change of linguistic elements for } \\
\text { paralinguistic elements. }\end{array}$ \\
\hline Transposition & Change of grammatical category \\
\hline Variation & $\begin{array}{l}\text { Change of linguistic or paralinguistic } \\
\text { elements that affect the aspects of } \\
\text { linguistic variation. }\end{array}$ \\
\hline
\end{tabular}

Note. Adopted from "Translation techniques revisited: A dynamic and functionalist approach" by L. Molina, A. Albir. 2002, Meta, 47(4), p. 498. Copyright 2002 by Les Presses de l’Université de Montréal.

\section{FINDINGS}

This section intends to address the research questions: (1) how is the rhetorical organization of the abstracts written in English and translated into Indonesian and vice versa illustrated in thesis abstracts and its translated version? and (2) what are translation techniques employed to translate the thesis abstracts written in English and translated into Indonesian and vice versa? The analysis result of the rhetorical move realized and translation techniques identified in abstracts across languages are discussed respectively.

\section{Move and Steps}

This section intends to present the moves and steps identified in the abstracts. In this context, salience is defined as the number of abstracts that featured the move or step (Kurniawan et al., 2019). Following Kanoksilapatham's (2005) criteria, the moves and the steps would be considered as optional if the occurrence is less than $66 \%$ in the data, conventional if it is between $66-99 \%$ of the data, and obligatory if the occurrence reaches $100 \%$ in the data. The table 
below presents the salience of the moves and steps (in percent) identified in the abstracts across languages in percentage.

Table 3. Occurrence of Move and Step in Abstracts across Languages (in percentage)

\begin{tabular}{ccccc}
\hline \multirow{2}{*}{$\begin{array}{c}\text { Move- } \\
\text { step }\end{array}$} & \multicolumn{2}{c}{ English } & \multicolumn{2}{c}{ Indonesian } \\
\cline { 2 - 5 } & English $\mathbf{( S T )} \mathbf{n}=\mathbf{1 5}$ & Indonesian (TT) & Indonesian $\mathbf{( S T )}$ & English (TT) \\
\hline Move 1 & 67 & 73 & 87 & 73 \\
Step 1 & 20 & 13 & 33 & 60 \\
Step 2 & 40 & 67 & 67 & 53 \\
Step 3 & 13 & 20 & 20 & 13 \\
Step 4 & 13 & 13 & 7 & 0 \\
Move 2 & 93 & 100 & 73 & 80 \\
Move 3 & 100 & 100 & 100 & 100 \\
Step 1 & 13 & 13 & 60 & 60 \\
Step 2 & 7 & 0 & 27 & 33 \\
Step 3 & 100 & 100 & 100 & 100 \\
Move 4 & 100 & 100 & 100 & 100 \\
Move 5 & 47 & 27 & 7 & 13 \\
Step 1 & 27 & 20 & 0 & 0 \\
Step 2 & 27 & 13 & 7 & 13 \\
Step 3 & 0 & 0 & 0 & 0 \\
Step 4 & 0 & 1 & 0 & 0 \\
\hline
\end{tabular}

Table 3 shows the percentage of each move and steps in the abstracts of its respective languages and the translations. The analysis revealed that all moves are manifested in the abstracts in different portions. Move 3 is the only move that appeared in all abstracts of both English and Indonesian language groups, with step 3 being the dominant step with 100\% occurrence across all groups. Move 4 appeared in almost every abstracts within the language groups. Move 5 is the move that is used the least with less than $30 \%$ salience in all of the language groups.

\section{Move 1 - Introduction}

This move is used to establish the context of a paper and motivates the research or discussion. In both English Language and Literature abstracts and Indonesian Language and Literature abstracts, there is a slight change in the occurrence of Move 1 in the ST and TT. In the ST of English Language and Literature abstracts, the occurrence of Move 1 increased from $67 \%$ to $73 \%$ while in Indonesian Language and Literature abstracts, it decreased from $87 \%$ to $73 \%$. This move is considered as conventional in the abstracts across languages. 
Move 2 - Purpose

Move 2 is used to indicate the purpose, thesis or hypothesis, or the intention of the study. This move is used a lot in the ST of English Language and Literature abstracts, with $93 \%$ occurrence. The number increased to $100 \%$ in the TT. This move is used less in the Indonesian Language and Literature abstracts. The occurrence differs in the ST and TT research abstracts as well.

Move 3 - Method

Move 3 has 100\% occurrence in English Literature and Indonesian Literature research abstracts, both in the ST and TT. Therefore, this move is regarded as obligatory in the data across languages. This move is used to provide information on research design, procedure, approach, data, etc.

Move 4 - Product

Move 4 stated main findings of a research. This move occurs in all of the English and Indonesian data, thus regarding this move as obligatory. This move and Move 3 - Method, are the only moves that appear consistently throughout the data.

\section{Move 5 - Conclusion}

This move draws the conclusion and offers inferences and implications of a study. Overall, this move appeared the least in comparison to other moves with the occurrence of under 50\% in both English and Indonesian ST abstracts and its translations. Like most of the other moves, the occurrence of Move 5 was not constantly the same in the ST abstract and TT abstract in both of the language groups.

Regarding the steps, it can be seen that Step 3 from Move 3 is the most prominent step as it occurred in all of the abstracts. Interestingly, there is a noticeable gap between the salience of Step 1 Move 3 and Step 2 Move 3 in the English language group and Indonesian language group.

\section{Steps of Move 1}

There is a significant rise in step 1 of Indonesian Language and Literature abstracts. In the ST abstracts, it only occurred 33\%. However, the occurrence of step 1 increased to $60 \%$ in the TT abstracts. Step 1 is used to argue for topic significance. The occurrence of other steps in this move also differs, but only by a slight margin.

\section{Steps of Move 3}

The step that was employed the most was step 3 which describes the procedure and context. This step has a consistent $100 \%$ occurrence, thus implying that it is an obligatory step. The other steps do not appear as 
frequently. Sometimes, step $1-$ describing participants and data sources and step 2 - describing instruments were employed as embedded steps. Step 2 is the only step in which salience is not consistent in the SL abstract and TL abstract.

\section{Steps of Move 5}

Steps of Move 5 are the ones that were the scarcest among the abstracts that were analyzed. Only Step 1, deducing conclusion, and Step 2, evaluating the significance of the study, were identified. Step 1 was only found in the English language group abstracts with the percentage of $27 \%$ in the ST and $20 \%$ in the TT.

\section{Translation Techniques}

This section illustrates the findings in relation to the translation techniques that were found in the abstracts.

Table 4. Occurrences of Translation Techniques in Abstracts across Languages (in percentage)

\begin{tabular}{|c|c|c|}
\hline Translation technique & $\begin{array}{c}\text { English } \\
f(\%), \mathrm{n}=15\end{array}$ & $\begin{array}{l}\text { Indonesian } \\
f(\%), \mathrm{n}=15\end{array}$ \\
\hline Adaptation & 7 & 7 \\
\hline Amplification & 20 & 0 \\
\hline Borrowing & 73 & 67 \\
\hline Calque & 73 & 7 \\
\hline Compensation & 40 & 7 \\
\hline Discursive creation & 0 & 7 \\
\hline Established equivalent & 20 & 13 \\
\hline Generalization & 20 & 0 \\
\hline Literal translation & 100 & 100 \\
\hline Modulation & 13 & 13 \\
\hline Reduction & 27 & 13 \\
\hline Transposition & 27 & 13 \\
\hline
\end{tabular}

Table 4 displays the percentage of translation techniques employed in English Language and Literature abstracts and Indonesian Language and Literature abstracts. From the table, it is visible that Literal Translation is the technique that is employed by both language groups with $100 \%$ occurrences. Literal translation is a technique of translating a source text into the target text word-for-word. This technique may be regarded as one of the easiest techniques to employ as it translates a passage word by word in a direct and literal way. This technique may cause the abstract writers to disregard grammatical rules and thus, make a translation mistake in their abstract. The 
translated sentence or passage may also feel unnatural to read if it is translated using this method.

ST: Thus, this study investigates the representation of Disney's white and non-white women in Brave (2012) and Moana (2016) produced by Walt Disney Studios in the $21^{\text {st }}$ century.

TT: Oleh karena itu, studi ini menginvestigasi reprsentasi perempuan kulit putih dan non kulit putih dalam film Brave (2012) dan Moana (2016) yang diproduksi Walt Disney Studios di abad ke-21.

(Abstract 2, English Language and Literature)

The second most used translation technique in both language groups is borrowing, with $73 \%$ occurring in the English language group and $67 \%$ occurring in the Indonesian language group. In theory, the borrowing technique uses a word or expression from a source language without any changes (pure borrowing) or changing the spelling to fit the spelling rules. In the abstracts of the English group, the authors employed pure borrowing to present a theoretical framework, findings, and conclusion.

ST: Two concepts, which are family projection process and nuclear family emotional process, are the triggers of child abuse. TT: Dua konsep, yaitu family projection process dan nuclear family emotional process, adalah pemicu kekerasan pada anak.

(Abstract 3, English Language and Literature)

In the abstracts of Indonesian groups, however, this technique is often used to adapt titles of works used as the data source. This is done to keep the originality of the title. The technique is also applied to Indonesian terms that have no English equivalent. Another way this technique is used is to mention institutions and places. Similar to the English students, Indonesian students also employ pure borrowing to translate the abstracts.

ST: Sumber datanya adalah Novel Elang Menoreh (Perjalanan Purwa Kala) Karya Wiwien Wintarto yang diterbitkan pada tahun 2018, 357 halaman.

TT: The data source for this study was Wiwien Wintarto's Novel entitled Elang Menoreh (Perjalanan Purwa Kala), published in 2018, 357 pages.

(Abstract 2, Indonesian Language and Literature) 
Another translation technique, calque, is also the second mostly used translation technique in the English language group. On the other hand, this translation technique only occurred $7 \%$ in the Indonesian language group. This technique translates a word or phrase literally, either lexically or structurally (Molina and Albir, 2002). This technique is different to Literal translation that translates a text word for word. In both language groups, this technique is employed to translate a cultural term or theoretical framework.

A huge occurrence gap of this translation technique seems quite noticeable. Presumably, this is because the technique was commonly used to translate a term or theoretical framework from a source text to a target text. The researchers assumed that in the Indonesian abstracts, the writers used the theories adapted from English books, so they did the calque translation process in writing their abstracts, not when they translate their abstract to English.

SL: Salah satu tradisi lisan tersebut adalah salawek dulang.

TL: One of the oral tradition is salawek tray.

(Abstract 14, Indonesian Language and Literature)

It is also worth noting that there are many sentences that are translated using more than one translation technique.

\section{DISCUSSION}

The findings above demonstrate the occurrence of the move-step and various translation techniques that were employed by undergraduate students in writing their research abstracts. Although the occurrence of the moves and steps in each data group may differ, it can be said that Move 3 - Method and Move 4 - Product are considered as obligatory moves regardless of the languages. This may mean that undergraduate students have the tendency to put emphasis on the methodology of the research and the findings of their research in their undergraduate thesis abstracts. Meanwhile, Move 1 and 2 are considered conventional in abstracts regardless of the language, occurring in around $66-99 \%$ of the abstracts. The only move that is regarded as optional across data groups is Move 5 as it is realized in less than $66 \%$ of the abstracts. This means that most of the abstracts did not state any conclusion and thus, are written in an incomplete structure. Moreover, regardless of the language, undergraduate students tend to not state the conclusion inferred from their study in their abstracts. It is possibly caused by the requirement of an abstract to be short and concise, and the students prioritize other moves to be realized. The findings are in line with Rashidi \& Meihami's (2018), who analyzed Scientometrics journal articles and discovered that method (Move 3) and results (Move 4) were provided the most frequently, while the information that was given the least in the abstracts was conclusion (Move 5). Furthermore, the results of this research show similar patterns with those 
presented by Juanda \& Kurniawan (2020) and Putri et al. (2021). However, Darabad's (2016) Darabad's (2016) study revealed that in three different disciplines (applied linguistics, applied mathematics, and applied chemistry), the least frequently occurring move was Move 1 - Introduction.

Regarding the steps, not all of the steps from all moves are realized. Step 1, 3, and 4 of Move 1 are all considered as optional step as those steps occur in less than $66 \%$ of the abstracts. On the other hand, step 2 of Move 1 is considered as conventional in the Indonesian abstracts of the English data $(67 \%)$ and Indonesian data $(67 \%)$. However, it is still considered as optional in the English abstracts of both data groups, occurring in $40 \%$ of the abstracts in the English data and 53\% in the abstracts of the Indonesian data. This shows that undergraduate students of the language study programs tend to realize Move 1 to state the generalization of the research topics. The difference in the occurrences of step 2 show that translation technique may have influenced the slight change in the occurrences, either by reducing or adding the information in the abstract. Regarding steps of Move 3, Step 3 of Move 3 has the highest occurrence in the data across languages, occurring in 100\% of the abstracts and is regarded as obligatory. On the other hand, step 1 and 2 are both considered conventional with generally low occurrence in the abstracts of the English data, and moderate occurrences in the Indonesian data. This is presumably because the students felt the need to mention the theoretical framework in their abstract, as it is a part that determines how the research will be conducted. By mentioning it in the beginning, the readers can get a gist of how the research was conducted. On the other hand, the steps of Move 5 are all realized in low occurrences and are considered as optional, while step 3 is not realized at all in the data. This finding is in line with several past studies that analyzed step realization in students' abstracts (Juanda \& Kurniawan, 2020; Putri et al., 2021). However, Pratiwi et al.'s (2021) findings in rhetorical move analysis of humanities and hard sciences' undergraduate thesis abstracts showed that step 3 of Move 3 is realized in a fairly low percentages. This shows that a further analysis with larger data may be needed to see a clearer pattern of undergraduate students' tendencies in realizing the steps in their abstracts.

The results regarding the rhetorical moves and steps show that undergraduate students tend to emphasize the methodology and product of the research in their abstracts. On the other hand, the conclusions drawn from their research were not commonly addressed in the study. The realization of moves and steps were realized in the same proportions regardless of language. It may imply that language difference in writing the abstracts did not influence the tendency of moves and steps realization in undergraduate thesis abstracts. 
As mentioned previously, Literal translation is the translation technique that is used in translating almost all of the moves in the abstracts. The technique is found in $100 \%$ of the abstracts, while many of the other translation techniques were employed as an embedded translation technique. Borrowing is the second-highest translation technique that occurred, but it is notable that there was a wide gap of occurrence between literal translation and the rest of the translation techniques, borrowing included. A prominent gap can also be seen in the occurrence of some translation techniques in abstracts of each data group, such as calque (73\% in English to $7 \%$ in Indonesian) and compensation (40\% in English to $7 \%$ in Indonesian). Furthermore, the analysis also found that most of the sentences were translated with one technique, while a small number were translated with two and three translation techniques at most.

The translation technique with highest occurrence found in this study differs from the result of previous research (Anwar et al., 2020; Kuswahono, 2020; Sodiq et al., 2020). Studies by those researchers stated that the translation technique that occurred the most in the texts they analyzed were linguistic compression (Anwar et al., 2020), which was not identified at all in the analyzed abstracts of this research, and pure borrowing (Kuswahono, 2020; Sodiq et al., 2020). On the other hand, Al Farisi's (2020) findings shows a similarity to this study's. His research found that literal translation was used the most. This may be influenced by the type of the text that is analyzed; Anwar and Kushwahono analyzed literary texts. Translator of fictional texts may adjust the translation by using translation techniques that may help the translator gain a translation that fits the culture of the target language while still keeping the meaning. On the other hand, the findings of Al Farisi's (2020) analysis which involved a formal text, showed a similarity to this study, implying that translator of formal texts may want to keep the translation as close to the target text as possible, thus employing literal translation to translate the texts.

The results imply that Literal Translation is the easiest translation technique to employ as it translates a sentence only word by word. While easy, this translation technique is prone to make a sentence come off as awkward and unnatural because the translator may not pay attention to the sentence structure of the target language. Translation techniques such as reduction or amplification, which are identified in some of the abstracts, may influence the difference in some of the moves and steps occurrence. Borrowing, the second most-used translation technique, is most commonly used to transfer terms from the source text to the target text. This may imply that undergraduate students tend to take terms from the source text and place them in the target text rather than translating it to the target language. These results were shown in both English and Indonesian data, meaning the 
majority of the abstracts are translated using similar techniques regardless of language differences. It is worth noting that there are many sentences that are translated with more than one translation technique, but most of them include Literal Translation. This caused the high occurrence gap between Literal Translation and borrowing.

It should be taken into consideration that the results of the present work are only concerned with undergraduate thesis abstracts of students in the English and Indonesian language field, and do not intend to generalize the quality of abstracts written by undergraduate students of other study programs. It is also worth noting that the year of the abstracts' publication was not considered during the data collection process due to the limited availability of the abstracts in Universitas Pendidikan Indonesia's online repository. Therefore, the findings of this research only show the rhetorical moves and translation techniques used in a small group of undergraduate students, and may not reflect the quality of undergraduate thesis abstracts as a whole. The result of the present study is expected to contribute to the existing literature related to academic writing, specifically for undergraduate students' thesis abstracts in English and Indonesian language study programs.

\section{CONCLUSION AND SUGGESTION}

This study aimed to identify move, steps, and translation techniques that were employed by students from two study programs in writing and translating their abstracts. The findings showed that all five moves and the related steps were employed in different portions, but the English data and Indonesian data showed similarities in realizing rhetorical moves and steps in their abstracts. Regarding the translation techniques, 12 were identified: adaptation, amplification, borrowing, calque, compensation discursive creation, established equivalent, generalization, literal translation, modulation, reduction, and transposition. The translation techniques may have changed the sentence structures and may have impacted the number of move and steps realized, which can be seen by the different occurrence percentage in ST abstracts and TT abstracts.

Based on the findings, this study concludes that Move 1, Move 2, Move 3 , and Move 4 are obligatory regardless of the language, and that Literal translation is the technique that was used the most. This implies that regardless of the language, undergraduate students tend to write their abstracts in a similar structure and translate them in a similar way as well.

This study recommends for researchers to conduct a similar research involving data sets obtained from different fields to see whether the rhetorical moves are realized similarly or not, to further enrich the existing knowledge related to this topic. Furthermore, a more in-depth analysis regarding 
translation techniques in academic fields is recommended to conduct as well. Additionally, this study also suggests for universities to guide students in writing and translating abstracts in order to achieve a good abstract and translation.

\section{ACKNOWLEDGEMENTS}

This study was a part of a bigger research and was supported by Indonesian University of Education's Research and Community Service Unit. The authors would like to express appreciation for all the support provided.

\section{REFERENCES}

Al Farisi, M. (2020). The impact of using foreignization and domestication on the translation accuracy of the Quranic metaphor (Kinayah) verses. Humanities and Management Sciences - Scientific Journal of King Faisal University, 21(1), 319-332. doi:https:/ / doi.org/10.37575/h/ rel/1966

Amnuai, W. (2019). Analyses of rhetorical moves and linguistic realizations in accounting research article abstracts published in International and Thaibased journals. SAGE Open, 9(1), 1-19. doi:https:/ / doi.org/10.1177/2158244018822384

Anwar, F. Z., Haryanti, D., \& Mukti, V. C. (2020). Translation techniques of expressive utterances used in the movie script of Aladdin. Proceedings of the 1st International Conference on Language, Literature, and Arts Education (ICLLAE 2019),

304-309. doi:https:/ / doi.org/10.2991/assehr.k.200804.060

Bassnett, S. (2014). Translation (The New Critical Idiom). Routledge.

Bhatia, V. K. (1993). Analysing Genre: Language Use in Professional Setting. Routledge.

Chalak, A., \& Norouzi, Z. (2013). Rhetorical moves and verb tense in abstracts: A comparative analysis of American and Iranian academic writing. International Journal of Language Studies, 7(4), 101-110.

Cross, C., \& Oppenheim, C. (2006). A genre analysis of scientific abstracts. Journal of Documentation, 62(4), 428-446. doi:https:/ / doi.org/10.1108/00220410610700953

Darabad, A. M. (2016). Move analysis of research article abstracts: A crossdisciplinary study. International Journal of Linguistics, 8(2), 125-140. doi:https:/ / doi.org/10.5296/ijl.v8i2.9379

Groves, M., \& Mundt, K. (2015). Friend or foe? Google translate in language for academic purposes. English for Specific Purposes, 37(2015), 112-121. doi:https:/ / doi.org/10.1016/j.esp.2014.09.001

Hyland, K. (2000). Disciplinary Discourses: Social Interactions in Academic Writing. University of Michigan Press.

Juanda, M. R., \& Kurniawan, E. (2020). A Comparison of Rhetorical Moves in 
Students' Undergraduate Thesis Abstracts. 509(Icollite), 443-448. doi:https:/ / doi.org/10.2991/assehr.k.201215.070

Kanoksilapatham, B. (2005). Rhetorical structure of biochemistry research articles. English for Specific Purposes, 24(3), 269-292. doi:https:/ / doi.org/10.1016/j.esp.2004.08.003

Koltay, T. (2010). Abstracts and Abstracting: A genre and set of skills for twentyfirst century (R. Rikowski (ed.); 1st ed.). Chandos Publishing.

Kurniawan, E., Lubis, A. H., Suherdi, D., \& Danuwijaya, A. A. (2019). Rhetorical organization of applied linguistics abstracts: Does scopus journal quartile matter? GEMA Online Journal of Language Studies, 19(4), 184-202. doi:https:// doi.org/10.17576/gema-2019-1904-10

Kuswahono, D. (2020). The use of translation techniques in translating cultural words in The Da Vinci Code Novel from English into Bahasa Indonesia. ANAPHORA: Journal of Language, Literary and Cultural Studies, 3(1), 38-46. https:/ / doi.org/10.30996/anaphora.v3i1.3642

Molina, L., \& Albir, A. H. (2002). Translation techniques revisited: A dynamic and functionalist approach. Meta, 47(4), 498-512. https:/ / doi.org/10.7202/008033ar

Pratiwi, D., Hermawan, B., \& Muniroh, R. D. (2021). Rhetorical move snalysis in humanities and hard science students' undergraduate thesis abstracts. Proceedings of the Thirteenth Conference on Applied Linguistics (CONAPLIN 2020), 546(Conaplin 2020), 121-126. https:/ / doi.org/10.2991/assehr.k.210427.019

Putri, F., Hermawan, B., \& Muniroh, R. D. (2021). Rhetorical move analysis in students' abstracts across degrees. Proceedings of the Thirteenth Conference on Applied Linguistics (CONAPLIN 2020), 546(Conaplin 2020), 162-167. https:/ / doi.org/10.2991/assehr.k.210427.025

Rashidi, N., \& Meihami, H. (2018). Informetrics of Scientometrics abstracts: a rhetorical move analysis of the research abstracts published in Scientometrics journal. Scientometrics, 116(3), 1975-1994. https:/ / doi.org/10.1007/s11192-018-2795-6

Sodiq, J., Budiman, T. C. S., \& Hidayat, N. (2020). Translation techniques in translating cultural issues in the Indonesian religious tourism brochure in Semarang City. International Journal of Research in Education, 1(1), 33-40.

Sukmawati, I. D., Hartono, R., \& Sutopo, D. (2021). Evaluating the quality of the Indonesia-English translation of research abstracts written by the Students of Harapan Bangsa University. English Education Journal, 11(1), 79-96. https:/ / doi.org/10.15294/EEJ.V11I1.40857 